\title{
The New Refugee Advocacy Staff Office
}

\author{
Ontario Legal Aid Plan
}

The Ontario Legal Aid Plan will be establishing a staff office in Toronto to represent refugee claimants at hearings before the Refugee Division of the Immigration and Refugee Board. This office will be established on a three year pilot project basis, and it is estimated that the office will represent about 1,150 refugee claimant cases annually. Refugee claimants who are entitled to legal aid retain the right to choose representation by staff counsel or counsel of their own selection retained on a legal aid certificate.

The feasibility of the delivery of legal aid to refugee claimants by a staff model clinic was examined by the Refugee Pilot Sub-Committee, a group of refugee lawyers, legal aid committee members and executive members of the Ontario Legal Aid Plan. Those representing the refugee lawyers bar were Joyce Chan, Greg James, Karen McCullough, Peter Showler and Lorne Waldman.

The Sub-Committee concluded that there is not a problem of access to legal services for refugee claimants in Ontario that would justify a method of delivery of those services different from the current method. However, there is to some extent a problem of access to competent legal services. Furthermore, the SubCommittee is of the view that the provincial government is committed to undertaking a pilot project to deliver legalservices to refugee claimants through astaff modelas a cost-savinginitiative. In those circumstances, the Sub-Committee believes that the Ontario Legal Aid Plan is in the best position, with the expertise and assistance of the private bar, to ensure that legal services delivered through a staff model are independent and of good quality and that proper resources are made available. It is within

Extracted from the "Report to the Legal Aid Committee of the Refugee Pilot Sub-Committee, June 1993," Ontario Legal Aid Plan. this context that the Sub-Committee made the recommendations that follow.

\section{Quality of Service}

The Sub-Committee concluded that the issue of paramount concern in refugee law cases was the quality of legal representation available to refugee claimants. There is often no remedy available for refugee claimants who have received incompetent representation. They face speedy deportation back to the country from which they fled.

There is a wide range of competence among lawyers representing refugee claimants. Members of the refugee bar who do appellate work have expressed concern about the lack of adequate preparation by somelawyers who represent refugee claimants at Board hearings. Comments about the competence of the representation of some lawyers should not, however, be taken to derogate from the overall contribution of the private bar to the body of refugee law that has developed rapidly in the last few years.

Refugee cases are becoming more vigorously contested. Counsel require greater advocacy skills and more detailed country knowledge to address arguments related to issues such as change in country conditions and the existence of an internal flight alternative. That is, as political changes occur in the countries from which refugee claimants have fled, their counsel must be familiar with those changes and must search out and submit to the Board information about the likely durability of the changes in order to address the reasonableness of the refugee claimant's continued fear of persecution should he or she return to that country. In addition, many arguments arise around what is termed the "internal flight alternative." In countries such as India and Sri Lanka, the Board may conclude that the refugee claimant would be likely to be safe in another part of the country other than the area from which he fled and accordingly, reject his or her refugee claim. Those are two examples of the many issues that now confront refugee lawyers in representing their refugee clients.

The newly amended Immigration Act permits the minister of immigration to intervene more often, and, as a result, cases will become lengthier and more complex legally. At the same time, the percentage of refugee claimants determined by the Immigration and Refugee Board (IRB) to be Convention refugees, and thus subject to Canada's protection, has fallen more than 75 percent from 1989 to 1992.

\section{Monitoring Quality of Service}

Monitoring the quality of representation of refugee claimants presents unusual difficulties that do not generally arise in other areas of practice. There are a number of reasons.

Hearings before the Refugee Division of the IRB are generally conducted in camera and do not permit the informal peer review of counsel's competencethat occurs naturally in criminal and family court where hearings are conducted in open court.

In addition, refugee claimants themselves are generally not knowledgeable consumers of legal services as are persons who have a greater connection with the structure of society in this culture. They are less likely to know that they are not being well served and to have knowledge of their ability to make a complaint to the Law Society of Upper Canada. Refugee claimants are vulnerable in a number of ways. Asa result of their experiences in the country from which they have fled, they are often distrustful and do not wish to call themselves to the attention of anyone in a position of authority in this country. If they are not well served and are determined not to be Convention refugees, they may well be deported before they are able to make a complaint about the quality of representation they received. 